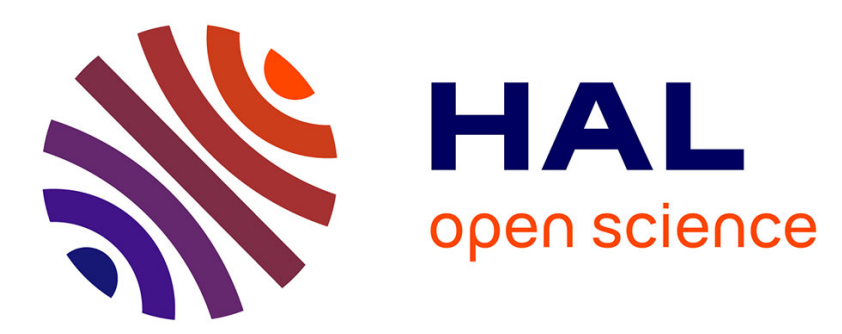

\title{
Characterization of genome-wide microsatellite markers in rabbitfishes, an important resource for artisanal fisheries in the Indo-West Pacific
}

Ilkser Erdem Kiper, Paulette Bloomer, Philippe Borsa, Thierry Bernard Hoareau

\section{To cite this version:}

Ilkser Erdem Kiper, Paulette Bloomer, Philippe Borsa, Thierry Bernard Hoareau. Characterization of genome-wide microsatellite markers in rabbitfishes, an important resource for artisanal fisheries in the Indo-West Pacific. Molecular Biology Reports, 2018, 45 (1), pp.19-25. 10.1007/s11033-017-4136-x . ird-01700836

\section{HAL Id: ird-01700836 \\ https://hal.ird.fr/ird-01700836}

Submitted on 5 Feb 2018

HAL is a multi-disciplinary open access archive for the deposit and dissemination of scientific research documents, whether they are published or not. The documents may come from teaching and research institutions in France or abroad, or from public or private research centers.
L'archive ouverte pluridisciplinaire HAL, est destinée au dépôt et à la diffusion de documents scientifiques de niveau recherche, publiés ou non, émanant des établissements d'enseignement et de recherche français ou étrangers, des laboratoires publics ou privés. 
To be cited as:

Kiper IE, Bloomer P, Borsa P, Hoareau TB (2018) Characterization of genome-wide microsatellite markers in rabbitfishes, an important resource for artisanal fisheries in the Indo-West Pacific. Molecular Biology Reports 45, 19-25. , doi:

$10.1007 / s 11033-017-4136-x$

Characterization of genome-wide microsatellite markers in rabbitfishes, an important resource for artisanal fisheries in the Indo-West Pacific

Ilkser Erdem Kiper 1,2, Paulette Bloomer 1,2, Philippe Borsa ${ }^{3}$, Thierry Bernard Hoareau ${ }^{1}, 2$

${ }^{1}$ Molecular Ecology and Evolution Programme, Department of GeneticsUniversity of PretoriaPrivate Bag X20, Hatfield, Pretoria 0028, South Africa

2 Department of Genetics, University of Pretoria, Private Bag X20 Hatfield 0028 South Africa

3 UMR 250 "Ecologie marine tropicale des océans Pacifique et Indien", Institut de recherche pour le développement (IRD), BP A5, 98848 Nouméa, New Caledonia

Molecular Ecology and Evolution Programme, Department of Genetics, University of Pretoria, Private Bag X20, Hatfield, Pretoria 0028, South Africa; Phone: +27(0)12 420 5062; Email: thoareau@gmail.com

Received: 23 September 2016 / Accepted: 12 December 2017 
Abstract Rabbitfishes are reef-associated fishes that support local fisheries throughout the Indo-West Pacific region. Sound management of the resource requires the development of molecular tools for appropriate stock delimitation of the different species in the family. Microsatellite markers were developed for the cordonnier Siganus sutor, and their potential for cross-amplification was investigated in 12 congeneric species. A library of 792 repeat-containing sequences was built. Nineteen sets of newly developed primers, and 14 universal finfish microsatellites were tested in S. sutor. Amplification success of the 19 Siganus-specific markers ranged from 32 to $79 \%$ in the 12 other Siganus species, slightly decreasing when the genetic distance of the target species to $S$. sutor increased. Seventeen of these markers were polymorphic in S. sutor and were further assayed in S. luridus, S. rivulatus, and S. spinus, of which respectively 9,10 and 8 were polymorphic. Statistical power analysis and an analysis of molecular variance showed that subtle genetic differentiation can be detected using these markers, highlighting their utility for the study of genetic diversity and population genetic structure in rabbitfishes.

Keywords Microsatellite resolution; Short-tandem repeat; Cross-species amplification; Siganus spp. 


\section{Introduction}

Rabbitfishes (genus Siganus) are Indo-West Pacific reef-associated fishes currently comprising 30 valid species $[1,2]$. These fishes are economically important as a food source in coastal areas across the Indo-West Pacific where they support local fisheries and aquaculture $[3,4,5,6,7]$. Overfishing threatens this resource, as in the case of the cordonnier Siganus sutor (Valenciennes 1835), along the coasts of eastern Africa [8,9]. Appropriate resource management requires the identification of demographically independent populations, which is often achieved using microsatellite markers [10]. The aim of the present study was to develop microsatellite markers for siganid fishes. To this end, we identified polymorphic microsatellite loci in a target species (S. sutor) and evaluated their utility as genetic markers in twelve other congeneric species.

\section{Materials and methods}

Siganus spp. fin tissue samples were obtained from several locations across the Indo-West Pacific (Online Resource 1). The rabbitfish species included in this study were $S$. argenteus, $S$. canaliculatus, $S$. corallinus, $S$. doliatus, S. fuscescens, S. laqueus, S. luridus, S. puellus, S. punctatus, S. rivulatus, S. spinus, S. sutor and S. vulpinus (Online Resource 1). Genomic DNA was extracted from fin tissue by using the DNeasy kit (Qiagen, Valencia CA, USA) following the manufacturer's protocol.

The microsatellite library was developed for $S$. sutor using the protocol of fast isolation by amplifiedfragment length polymorphism of sequences containing repeats, which involves a protocol based on digestion and ligation reactions [11] combined to 454 sequencing [12]. We followed the same procedures as [13]. Genomic DNA was fragmented by enzyme digestion using the restriction enzyme MseI (New England Biolabs, Ipswich, MA). This was followed by the ligation of the small fragments to an adaptor (5'TACTCAGGACTCAT-3'/5'-GACGATGAGGTCCTGAG-3') [11,13]. The ligation products were then hybridized to the repeat containing biotinylated probes $\left(\mathrm{CAAA}_{6}, \mathrm{GAAA}_{6}\right.$, and $\left.\mathrm{GATA}_{6}\right)$ [14] and the hybridized regions were captured on streptavidin-coated beads (Roche, Basel, Switzerland). After hybridization, non-specific binding elements were removed by washing. The eluted DNA, which consists of chemically and heat-separated DNA fragments containing selected repeats removed from the probes, was amplified according to [11] and the amplification product was pyrosequenced using GS-FLX titanium reagents by the 454 Genome Sequencer FLX ${ }^{\mathrm{TM}}$ (Inqaba Biotech, Pretoria, South Africa).

The repeat-enriched sequence library was mined for potential microsatellites, i.e., nucleotide sequences containing $\geq 8$ short tandem repeats for all the repeat types including mono-, di-, tri-, tetra-, penta- and hexanucleotides, using MSATCOMMANDER v. 0.8.2 [15]. Sequences > 100-bp long were selected to ensure adequate flanking regions for primer design. Duplications were verified using the online version of the alignment program MAFFT (http://mafft.cbrc.jp/alignment/server/), selecting the default settings, but choosing the option for adjusting the direction of nucleotide sequences. A single copy of identical sequences was kept. The program PRIMER DESIGNER v. 4.20 (SECentral, Scientific \& Educational Software, Durham NC, USA) was used to generate 59 primer sets based on standard criteria (Online Resources 2-4). A total of 19 of these primer sets were selected for further tests. Additionally, we included 14 microsatellite markers that universally amplify in acanthopterygian fishes [16]. All 33 markers were used for cross-species amplification in S. sutor and the 12 other siganid species. A total of 17 markers found to be polymorphic in S. sutor were further genotyped in three other species, S. spinus, S. luridus and S. rivulatus. 
Amplification reactions were done in $10 \mu \mathrm{L}$ volumes and the reaction mixture included $\sim 40 \mathrm{ng}$ of template DNA, $1 \times$ PCR buffer, $1.5 \mathrm{mM} \mathrm{MgCl}_{2}, 0.2 \mathrm{mM}$ dNTPs (Promega, Madison WI, USA), $0.2 \mathrm{pM}$ primers (Whitehead Scientific, Johannesburg, South Africa), and 0.04 U Supertherm Taq polymerase (Southern Cross Biotechnologies, Cape Town, South Africa). The PCR cycling conditions were: $94{ }^{\circ} \mathrm{C}$ for $5 \mathrm{~min}$, followed by 30 cycles of $94^{\circ} \mathrm{C}$ for $30 \mathrm{~s}, 1 \mathrm{~min}$ at annealing temperature (details in Online Resource 3), $72{ }^{\circ} \mathrm{C}$ for $1 \mathrm{~min}$ and by a final elongation at $72{ }^{\circ} \mathrm{C}$ for $7 \mathrm{~min}$. Amplification products were subjected to electrophoresis on 3\% agarose gels $(1.5 \mathrm{~h}, 100 \mathrm{~V})$ and visualised with GelRed ${ }^{\text {TM }}$ stain (Biotium, Hayward CA, USA). The amplification reactions were repeated using fluorescently-labelled ChromaTide ${ }^{\circledR}$ Alexa Fluor ${ }^{\mathrm{TM}}$ 488-5-dUTPs (Invitrogen, Carlsbad CA, USA) to confirm the presence of multiple alleles at each locus. Forward primers of Siganus-specific loci that were polymorphic were labelled by the fluorescent G5 dye set (Applied Biosystems, Foster City CA, USA). Genotyping was done using the Quantitect Multiplex PCR kit (Qiagen), following the manufacturer's recommendations. The fragments were analysed on an ABI 3500xl genetic analyzer (Applied Biosystems) with the GeneScan Liz ${ }^{\mathrm{TM}} 500$ Size Standard (Applied Biosystems). Scoring of genotypes was done using the GENEMARKER v. 1.5 software (SoftGenetics, State Collage, Pennsylvania, USA).

To investigate the transferability of the 19 new Siganus-specific markers across the family, we evaluated the relationship between genetic distance to the target species $S$. sutor and cross-species amplification success. To estimate genetic distance, nucleotide sequences of the mitochondrial cytochrome b (cytb) gene were used. This included sequences available from GenBank (Online Resource 5) and new sequences generated in the present study (Online Resource 6). We followed the procedure described in [17] to design specific primers for the family Siganidae. Cycling conditions included initial denaturation at $94^{\circ} \mathrm{C}$ for $3 \mathrm{~min} ; 35$ cycles of denaturation at $94^{\circ} \mathrm{C}$ for $30 \mathrm{~s}$, annealing at $55^{\circ} \mathrm{C}$ for $30 \mathrm{~s}$, elongation at $72^{\circ} \mathrm{C}$ for $1 \mathrm{~min}$; and final elongation at $72^{\circ} \mathrm{C}$ for $7 \mathrm{~min}$. The amplified products were precipitated using 2.8 volumes of absolute ethanol, 0.4 volumes of Sabax water and 0.08 volumes of 3M sodium acetate, followed by a washing step using $90 \mu \mathrm{L} 70 \%$ ethanol. The products were eluted in $15 \mu \mathrm{L}$ Sabax water. Cycle sequencing reactions contained approximately $30 \mathrm{ng}$ purified DNA, $1 \mu \mathrm{L}$ ABI PRISM BigDye Terminator Cycle Sequencing Ready Reaction Kit v. 3.1 (Applied Biosystems), $5 \mathrm{x}$ sequencing buffer and $3.2 \mathrm{pM}$ primer. Sequencing was done on an ABI 3500xl sequencer (Applied Biosystems).

Genetic distance between species was estimated as the net mean nucleotide divergence (Kimura-2parameter model; MEGA6) [18] at the cytb locus between S. sutor and the other species considered. The distances were used to reconstruct a Neighbor-Joining tree in MEGA6, to illustrate the diversity of species used in the present study and their phylogenetic relationships (Fig. 1a). The GenBank sequences that represented possibly misidentified specimens, possible mitochondrial-DNA introgression or cryptic species were removed from the analysis (Online Resource 5).

Summary statistics on the microsatellite genotype data, and their significance, were estimated using GENETIX v.4.05 [19]. The possible presence of null alleles was assessed using MiCROCHECKER v. 2.2 .3 [20]. Linkage disequilibrium (LD) among markers was estimated and tested using permutation tests in ARLEQUIN v. 3.0 [21]. BAYESCAN v. 2.1 [22] and LOSITAN [23] were used to detect potential outlier loci based on allelic differences estimated by $F_{\mathrm{ST}}$, and comparison between the observed $F_{\mathrm{ST}}$ and expected heterozygosity among the populations, respectively. We used the program PowsiM v. 4.1 [24] to evaluate the statistical power of the markers to detect subtle genetic structure. This program identifies the threshold above which $F_{\text {ST values }}$ become significant, given the distribution of allele frequencies in a set of markers. The specific test that we performed relied on simulated pairs of populations (100 replicates) with a set sample size (50 individuals) and 
effective population size $\left(N_{\mathrm{e}}=5000\right)$, but a varying number of generations since isolation $(t=5-300)$ to generate various levels of divergence (i.e. $F_{\mathrm{ST}}$ values). To further evaluate the utility of the markers with regards to potential spatial genetic structuring, an analysis of molecular variance (AMOVA) [25] was done among samples of $S$. spinus and $S$. luridus, the two species from the study with multiple samples from different locations. Each sampling location was defined as a population (see Online Resource 1). The significance of the variance components among populations and within populations was determined using 1000 permutations.

\section{Results and discussion}

The repeat-enriched library contained 6112 sequences and the mining step uncovered 310, 61, and 421 sequences containing di-, tri- and tetra-nucleotide repeats, respectively (Online Resource 7). Only a subset of these sequences was longer than $100 \mathrm{bp}$ and contained sufficiently long flanking regions at both ends. These included 28, 12, and 38 sequences containing di-, tri-, and tetra-nucleotide repeats, respectively. Among these, 59 sequences were used for primer design (Online Resource 2). Due to budget limitations, only 19 of these potential markers were tested for amplification in 13 Siganus species, including S. sutor.

Cross-species amplification success of the 33 markers (of which 19 were Siganus-specific and14 were universal in ray-finned fishes) across 12 siganids ranged from 36\% (S. laqueus) to $76 \%$ (S. corallinus, S. doliatus and $S$. fuscescens). The genetic distance to $S$. sutor, estimated from nucleotide sequences at the cytb locus, ranged from 0.035 (S. rivulatus) to 0.165 (S. argenteus) (Online Resource 8). The amplification success of the 19 Siganusspecific markers ranged from 32\% (in S. vulpinus) to 79\% (in S. fuscescens) (Fig. 1a) and showed a weak yet significant decrease with the genetic distance to $S$. sutor (Fig. 1b). The new microsatellite markers therefore amplify in species other than $S$. sutor but phylogenetic distance affects the amplification efficiency. Alternative primers might need to be designed for the few markers that do not, or poorly amplify in some species. Similar negative correlation has been reported previously $[13,26]$. This trend is likely a general one across taxa and markers, and should be accounted for in the evaluation of cross-species amplification.

Twelve of the 19 Siganus-specific markers and five of the universal acanthopterygian fish markers were polymorphic in S. sutor (Online Resource 3). These were tested for polymorphism in three other siganid species (Table 1). The expected heterozygosity averaged across all loci was 0.822 for $S$. luridus, 0.753 for $S$. rivulatus, 0.682 for $S$. spinus, and 0.823 for $S$. sutor, while the mean number of alleles across loci was $8.78,5.73$, 6.75, and 11.69, respectively. Significant deviation from Hardy-Weinberg equilibrium was detected at 3/9 loci in S. luridus, 1/11 loci in S. rivulatus, 2/8 loci in S. spinus, and 7/17 loci in S. sutor, but null alleles were detected in only a smaller proportion of the loci: SIG006 in S. spinus, and SIG008 and SIG013 in S. sutor. Significant linkage disequilibrium values were detected for 2/28 locus-pairwise comparisons in S. spinus (Online Resource 9) and for 5/120 comparisons in S. sutor, after Bonferroni correction [27] (Online Resource 10). Considering the low occurrence of significant values, both null alleles and linkage disequilibrium are expected to have a marginal effect on the analysis of genetic differentiation between populations in S. spinus and $S$. sutor. BAYESCAN [22] and LOSITAN [23] detected a single outlier locus (SIG017), relative to the level of genetic differentiation between populations. The occurrence at this locus of an $F_{\text {ST }}$ value above the $99 \%$ confidence interval suggests directional selection, but this can also be due to non-overlapping allele sizes between species.

By assessing the resolution power of the microsatellite markers, we were able to evaluate whether the sets of microsatellites in $S$. rivulatus, $S$. spinus and $S$. sutor could potentially identify genetically distinct populations. A previous simulation study showed that the threshold $F_{\text {ST }}$ values for the detection of genetic subdivision 
among populations ranged from as low as 0.005-0.007 when using the appropriate set of markers [29]. In the present study, the set of microsatellite markers was able to detect subtle levels of genetic differentiation through the power analysis. These values were as low as $F_{\mathrm{ST}}=0.0135$ in $S$. luridus, $F_{\mathrm{ST}}=0.015$ in S. spinus, and $F_{\mathrm{ST}}=0.011$ in $S$. sutor (Fig. 2); S. rivulatus was excluded from this analysis due to low sample sizes. These results based on simulations were confirmed by the AMOVA analyses, which showed significant genetic differentiation among locations in both $S$. luridus $\left(F_{\mathrm{ST}}=0.152, P=0.001\right)$ and $S$. spinus $\left(F_{\mathrm{ST}}=0.077\right.$, $P=0.021)$ despite low sample sizes per location ranging from one to ten (Table 2). The set of markers proposed in this study therefore proved useful in detecting subtle genetic structure in Siganus spp.

The amplification success, the level of polymorphism, the resolution power, and the pilot study for the detection of population differentiation show that these microsatellites represent a valuable molecular resource for rabbitfish species. These markers will be useful for developing studies aimed at improving resource management in artisanal rabbitfish fisheries across the Indo-West Pacific.

\section{Acknowledgements}

We would like to thank the following collaborators for facilitating the collection of samples: A. Brito and R. Mutombene from the Instituto Nacional de lnvestiqacao Pesqueira (Mozambique), N. Wambiji from the Marine \& Fisheries Research Institute (Kenya), S. Abeare from Reef Doctor (Madagascar), G. Gouws from the South African Institute for Aquatic Biodiversity (South Africa), A. Collet, G. Mou-Tham and D. Lecchini from IRD (New Caledonia), P. Boblin and E. Tardy from SPC (New Caledonia), E. Tessier from Parc Marin (La Réunion), F. Giancarlo from Proyek Biokor (Indonesia and West Papua), M. Hassan from SMEL (France), and M. Low from NUS (Singapore).

\section{Funding}

This project was funded by the Western Indian Ocean Marine Science Association (WIOMSA): MARG I/11/2013 and the South African Department of Science and Technology/National Research Foundation African Coelacanth Ecosystem Programme (ACEP) II. Sampling was funded in part by IRD, SPC and SAIAB. IEK benefitted from a PhD scholarship from the University of Pretoria's PhD programme. TBH was supported by the University of Pretoria's research fellowship programme and the University of Pretoria Research Development Programme.

\section{Conflict of interest}

We have no conflict of interest regarding the content of the present paper.

\section{References}

1. Froese R, Pauly D (2016) FishBase. World Wide Web electronic publication. http://www.fishbase.org. Accessed 23 Mar 2016

2. Eschmeyer WN, Fricke R, van der Laar R (2016) Catalog of fishes: genera, species, references, electronic version. http://researcharchive.calacademy.org/research/ichthyology/catalog/. Accessed 23 Mar 2016

3. Lam TJ (1974) Siganids: their biology and mariculture potential. Aquaculture 3:325-354 
4. Woodland DJ (1990) Revision of the fish family Siganidae with description of two new species and comments on distribution and biology. Indo-Pac Fishes 19:1-136

5. Kuiter R (1993) Coastal fishes of south-eastern Australia. University of Hawaii Press, Honolulu

6. Kuriiwa K, Hanzawa N, Yoshino T, Kimura S, Nishida M (2007) Phylogenetic relationships and natural hybridization in rabbitfishes (Teleostei: Siganidae) inferred from mitochondrial and nuclear DNA analyses. Mol Phylogenet Evol 45:69-80

7. Lemer S, Aurelle D, Vigliola L, Durand J-D, Borsa P (2007) Cytochrome $b$ barcoding, molecular systematics, and geographic differentiation in rabbitfishes (Siganidae). C R Biol 330:86-94

8. Wambiji N (2010) Reproductive biology of three siganid species: Siganus canaliculatus (Park 1797), Siganus sutor (Valenciennes 1835) and Siganus stellatus (Forsskal 1775) in family Siganidae along the Kenyan coast. Kenya Marine and Fisheries Institute, Mombasa, Mombasa

9. Samoilys MA, Osuka K, Maina GW, Obura D (2017) Artisanal fisheries on Kenya's coral reefs: decadal trends reveal management needs. Fish Res 186:177-191

10. Selkoe KA, Toonen RJ (2006) Microsatellites for ecologists: a practical guide to using and evaluating microsatellite markers. Ecol Lett 9:615-629

11. Zane L, Bargelloni L, Patarnello T (2002) Strategies for microsatellite isolation: a review. Mol Ecol 11:116

12. Abdelkrim J, Roberson BC, Stanton JL, Gemmell NJ (2009) Fast, cost-effective development of speciesspecific microsatellite markers by genomic sequencing. Biotechniques 46:185-192

13. Reid K, Hoareau TB, Bloomer P (2012) High-throughput microsatellite marker development in two sparid species and verification of their transferability in the family Sparidae. Mol Ecol Resour 12:740-752

14. Tóth G, Gáspári Z, Jurka J (2000) Microsatellites in different eukaryotic genomes: survey and analysis. Genome Res 10:967-981

15. Faircloth BC (2008) MSATCOMMANDER: detection of microsatellite repeat arrays and automated, locusspecific primer design. Mol Ecol Resour 8:92-94

16. Gotoh R, Tamate S, Yokoyama J, Tamate HB, Hanzawa N (2013) Characterization of comparative genome-derived simple sequence repeats for acanthopterygian fishes. Mol Ecol Resour 13:461-472

17. Hoareau TB, Boissin E (2010) Design of phylum-specific hybrid primers for DNA barcoding: addressing the need for efficient COI amplification in the Echinodermata. Mol Ecol Resour 10:960-967

18. Tamura K, Stecher G, Peterson D, Filipski A, Kumar S (2013) MEga6: molecular evolutionary genetics analysis version 6.0. Mol Biol Evol 30:2725-2729

19. Belkhir K, Borsa P, Chikhi L, Raufaste N, Bonhomme F (2004) GENETIX 4.05, logiciel sous WINDOwsTM pour la génétique des populations. Laboratoire Génome, Populations, Interactions, CNRS UMR 5171, Université Montpellier II, Montpellier

20. Van Oosterhout C, Hutchinson WF, Wills DP, Shipley P (2004) MICRO-CHECKER: software for identifying and correcting genotyping errors in microsatellite data. Mol Ecol Notes 4:535-538

21. Excoffier L, Laval G, Schneider S (2005) ARLEQUIN (ver. 3.0): an integrated software package for population genetics data analysis. Evol Bioinform Online 1:47-50

22. Foll M, Gaggiotti O (2008) A genome-scan method to identify selected loci appropriate for both dominant and codominant markers: a Bayesian perspective. Genetics 180:977-993

23. Antao T, Lopes A, Lopes RJ, Beja-Pereira A, Luikart G (2008) LOSITAN: a workbench to detect molecular

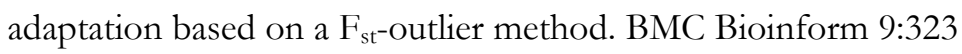


24. Ryman N, Palm S (2006) PowsIM: A computer program for assessing statistical power when testing for genetic differentiation. Mol Ecol 6:600-602

25. Excoffier L, Smouse PE, Quattro JM (1992) Analysis of molecular variance inferred from metric distances among DNA haplotypes: application to human mitochondrial DNA restriction data. Genetics 131:479_ 491

26. Carreras-Carbonell J, Macpherson E, Pascual M (2008) Utility of pairwise mtDNA genetic distance for predicting cross-species microsatellite amplification and polymorphism success in fishes. Conserv Genet 9:181-190

27. Rice WR (1989) Analyzing tables of statistical tests. Evolution 43:223-225

28. Weir BS, Cockerham CC (1984) Estimating F-Statistics for the analysis of population structure. Evolution 38:1358-1370

29. Waples RS, Gaggiotti O (2006) What is a population? An empirical evaluation of some genetic methods for identifying the number of gene pools and their degree of connectivity. Mol Ecol 15:1419-1439 
Table 1 Summary statistics for 17 polymorphic loci tested in four siganids (with sample size in brackets) including the number of observed alleles $\left(N_{\mathrm{A}}\right)$, expected heterozygosity $\left(H_{\mathrm{E}}\right)$, observed heterozygosity $\left(H_{\mathrm{O}}\right)$, and inbreeding coefficient $\left(F_{\mathrm{IS}}\right)$ estimates [28]

\begin{tabular}{|c|c|c|c|c|c|}
\hline \multirow[t]{2}{*}{ Locus } & \multirow[t]{2}{*}{ Statistic } & \multicolumn{4}{|l|}{ Species } \\
\hline & & S. luridus (17) & S. rivulatus (7) & S. spinus (20) & S. sutor (32) \\
\hline \multicolumn{6}{|c|}{ ORLA2-91 } \\
\hline & $N_{\mathrm{A}}$ & 13 & 6 & 12 & 14 \\
\hline & $H_{\mathrm{E}}$ & 0.927 & 0.929 & 0.840 & 0.905 \\
\hline & $H_{\mathrm{O}}$ & 0.882 & 1 & 0.700 & 0.931 \\
\hline & $F_{\mathrm{IS}}$ & 0.050 & -0.091 & $0.191^{* * *}$ & -0.029 \\
\hline \multicolumn{6}{|c|}{ ORL A8-113 } \\
\hline & $N_{\mathrm{A}}$ & 8 & 1 & 11 & 4 \\
\hline & $H_{\mathrm{E}}$ & 0.831 & 0 & 0.853 & 0.696 \\
\hline & $H_{\mathrm{O}}$ & 0.625 & 0 & 0.900 & 0.594 \\
\hline & $F_{\mathrm{IS}}$ & $0.254 *$ & 0 & -0.030 & 0.149 \\
\hline \multicolumn{6}{|c|}{ ORLA11-71 } \\
\hline & $N_{\mathrm{A}}$ & 5 & 2 & 4 & 5 \\
\hline & $H_{\mathrm{E}}$ & 0.546 & 0.533 & 0.650 & 0.668 \\
\hline & $H_{\mathrm{O}}$ & 0.588 & 0.400 & 0.700 & 0.719 \\
\hline & $F_{\mathrm{IS}}$ & -0.081 & 0.273 & -0.051 & -0.078 \\
\hline \multicolumn{6}{|c|}{ ORL A12-160 } \\
\hline & $N_{\mathrm{A}}$ & NA & $\mathrm{MD}$ & 11 & 11 \\
\hline & $H_{\mathrm{E}}$ & & & 0.837 & 0.883 \\
\hline & $H_{\mathrm{O}}$ & & & 0.824 & 0.906 \\
\hline & $F_{\mathrm{IS}}$ & & & 0.047 & -0.027 \\
\hline \multicolumn{6}{|c|}{ ORLA14-42 } \\
\hline & $N_{\mathrm{A}}$ & 15 & 5 & 5 & 17 \\
\hline & $H_{\mathrm{E}}$ & 0.944 & 0.800 & 0.555 & 0.913 \\
\hline & $H_{\mathrm{O}}$ & 0.857 & 1 & 0.650 & 0.844 \\
\hline & $F_{\mathrm{IS}}$ & 0.096 & -0.290 & -0.146 & 0.077 \\
\hline \multicolumn{6}{|c|}{ SIG006 } \\
\hline & $N_{\mathrm{A}}$ & NA & 7 & 3 & 8 \\
\hline & $H_{\mathrm{E}}$ & & 0.890 & 0.539 & 0.732 \\
\hline & $H_{\mathrm{O}}$ & & 1 & 0.300 & 0.406 \\
\hline & $F_{\mathrm{IS}}$ & & -0.135 & $0.464 * * *$ & $0.449 * * *$ \\
\hline \multicolumn{6}{|c|}{ SIG007 } \\
\hline & $N_{\mathrm{A}}$ & 7 & 4 & $\mathrm{NA}$ & 10 \\
\hline & $H_{\mathrm{E}}$ & 0.836 & 0.714 & & 0.780 \\
\hline & $H_{\mathrm{O}}$ & 0.546 & 0.857 & & 0.677 \\
\hline & $F_{\mathrm{IS}}$ & $0.358^{* * *}$ & -0.220 & & 0.133 \\
\hline \multicolumn{6}{|c|}{ SIG008 } \\
\hline & $N_{\mathrm{A}}$ & NA & NA & $\mathrm{NA}$ & 11 \\
\hline & $H_{\mathrm{E}}$ & & & & 0.882 \\
\hline & $H_{\mathrm{O}}$ & & & & 0.308 \\
\hline & $F_{\mathrm{IS}}$ & & & & $0.655^{* * *}$ \\
\hline \multicolumn{6}{|c|}{ SIG009 } \\
\hline & $N_{\mathrm{A}}$ & $\mathrm{MD}$ & 11 & $\mathrm{MD}$ & 23 \\
\hline & $H_{\mathrm{E}}$ & & 0.956 & & 0.953 \\
\hline & $H_{\mathrm{O}}$ & & 1 & & 0.739 \\
\hline & $F_{\mathrm{IS}}$ & & -0.050 & & $0.228^{* * *}$ \\
\hline \multicolumn{6}{|c|}{ SIG010 } \\
\hline & $N_{\mathrm{a}}$ & $\mathrm{MD}$ & $\mathrm{MD}$ & NA & 16 \\
\hline & $H_{\mathrm{E}}$ & & & & 0.886 \\
\hline & $H_{\mathrm{O}}$ & & & & 0.636 \\
\hline & $F_{\mathrm{IS}}$ & & & & $0.286^{* * *}$ \\
\hline \multicolumn{6}{|c|}{ SIG011 } \\
\hline & $N_{\mathrm{A}}$ & 9 & 7 & 5 & 16 \\
\hline & $H_{\mathrm{E}}$ & 0.874 & 0.933 & 0.709 & 0.937 \\
\hline & $H_{\mathrm{O}}$ & 0.769 & 1 & 0.600 & 0.760 \\
\hline & $F_{\mathrm{IS}}$ & 0.124 & -0.081 & 0.178 & $0.192^{* * *}$ \\
\hline
\end{tabular}




\begin{tabular}{|c|c|c|c|c|c|}
\hline & $\begin{array}{l}N_{\mathrm{A}} \\
H_{\mathrm{E}} \\
H_{\mathrm{O}} \\
F_{\mathrm{IS}}\end{array}$ & $\mathrm{MD}$ & $\mathrm{NA}$ & $\mathrm{MD}$ & $\begin{array}{l}5 \\
0.658 \\
0.044 \\
0.935^{* * *}\end{array}$ \\
\hline \multicolumn{6}{|l|}{ SIG014 } \\
\hline & $N_{\mathrm{A}}$ & 12 & 8 & MD & MD \\
\hline & $H_{\mathrm{E}}$ & 0.909 & 0.912 & & \\
\hline & $H_{\mathrm{O}}$ & 0.688 & 0.714 & & \\
\hline & $F_{\text {IS }}$ & $0.250^{*}$ & 0.231 & & \\
\hline SIG015 & $N_{A}$ & NA & NA & $\mathrm{NA}$ & 15 \\
\hline & $H_{\mathrm{E}}$ & & & & 0.899 \\
\hline & $H_{\mathrm{O}}$ & & & & 0.781 \\
\hline & $F_{\mathrm{IS}}$ & & & & $0.133^{*}$ \\
\hline \multicolumn{6}{|l|}{ SIG017 } \\
\hline & $\mathrm{N}_{\mathrm{a}}$ & 5 & 6 & 3 & 6 \\
\hline & $\begin{array}{l}H_{\mathrm{E}} \\
H_{\mathrm{O}}\end{array}$ & 0.647 & 0.714 & 0.400 & $\begin{array}{l}0.691 \\
0.625\end{array}$ \\
\hline & $F_{\text {IS }}$ & 0.088 & 0.048 & 0.176 & 0.096 \\
\hline \multicolumn{6}{|l|}{ SIG019 } \\
\hline & $H_{\mathrm{F}}$ & $N A$ & $N A$ & MII & $\begin{array}{l}12 \\
0.806\end{array}$ \\
\hline & $H_{\mathrm{O}}$ & & & & 0.781 \\
\hline & $F_{\text {IS }}$ & & & & 0.031 \\
\hline SIG020 & $N_{A}$ & 5 & 6 & $\mathrm{NA}$ & 14 \\
\hline & $H_{\mathrm{E}}$ & 0.822 & 0.864 & & 0.880 \\
\hline & $H_{\mathrm{O}}$ & 0.800 & 0.500 & & 0.857 \\
\hline & $F_{\text {IS }}$ & 0.030 & $0.444 *$ & & 0.044 \\
\hline
\end{tabular}


Table 2 Analysis of molecular variance for Siganus luridus and Siganus spinus. Degrees of freedom (df), percentage contribution to overall genetic variance $(\mathrm{GV} \%)$ and fixation index $\left(F_{\mathrm{ST}}\right)$ with related $P$-value are presented.

\begin{tabular}{llllll}
\hline Species & Source of variation & $\mathrm{df}$ & $\mathrm{GV} \%$ & Fixation index & $P$-value \\
\hline S. luridus & Among populations & 2 & 15.19 & $F_{\text {ST }}: 0.152$ & 0.001 \\
& Within populations & 31 & 84.81 & & \\
S. spinus & Among populations & 4 & 7.67 & $F_{\text {ST }}: 0.077$ & 0.021 \\
& Within populations & 35 & 92.33 & & \\
\hline
\end{tabular}




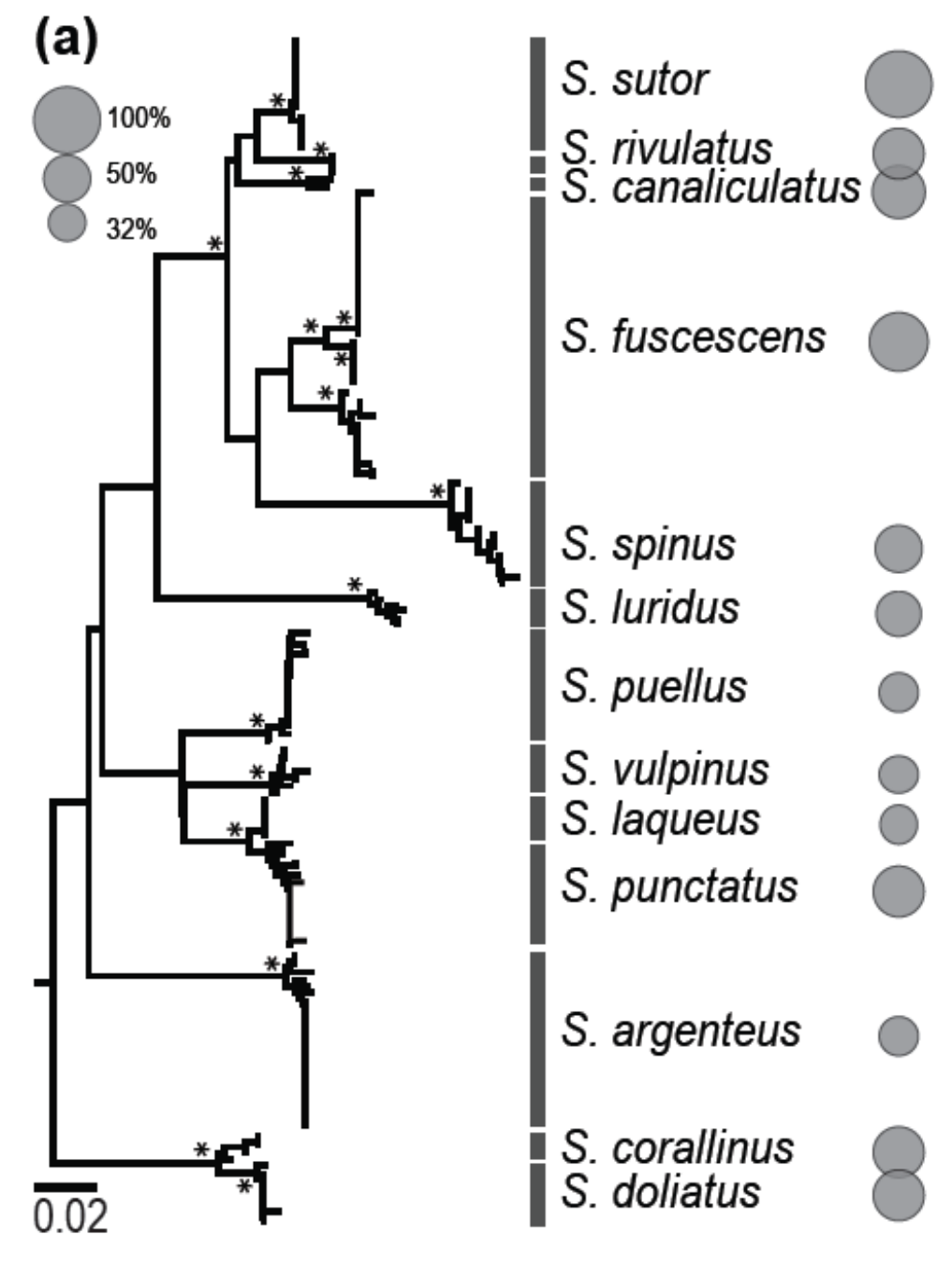

(b)

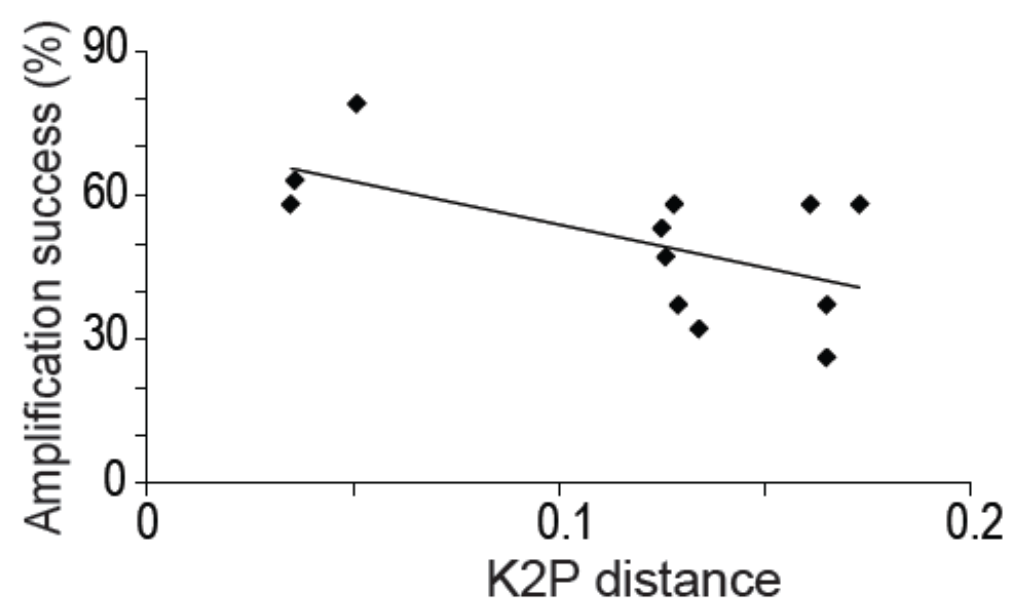

Fig. 1 Amplification success of the new set of 19 microsatellites in 13 Siganus species. a Genetic relationships among 13 Siganus species illustrated by a Neighbour Joining tree based on 184 gytochrome $b$ gene sequences [MEGA6: Kimura-2 parameter (K2P) model; pairwise deletion] [18]. The amplification success of the 19 loci represented by circles whose surface is proportional to the proportion of amplifying loci. Supported nodes ( $\geq 75 \%$ bootstrap score) are indicated with a star. cytb gene sequences of three surgeonfish species (Acanthurus blochii, A. triostegus, Naso unicornis) were chosen as outgroup. b Amplification success plotted against K2P distance to $S$. sutor. Linear regression model: $y=-0.0178 x+0.7172, R=0.3531$. The null hypothesis that the slope is equal to 0 was rejected $(F=5.46 ; P=0.042)$. 


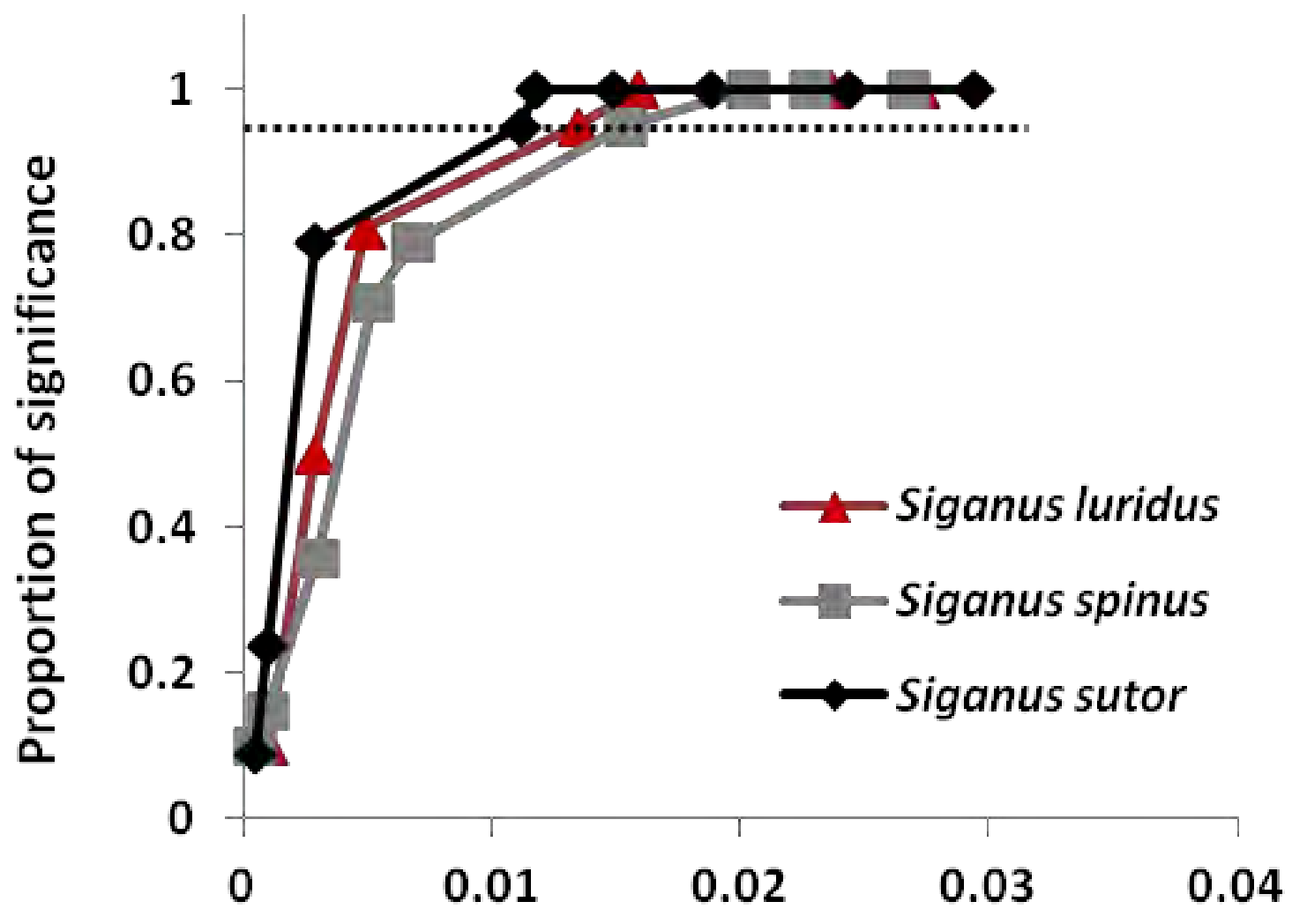

FST

Fig. 2 Power analysis for the set of polymorphic microsatellite markers illustrating the proportion of significance $(P S)$ as a function of the $F_{\mathrm{ST}}$ value in $S$. luridus (9 loci; 17 individuals; $P S=2.076+0.261 . \ln \left(F_{\mathrm{ST}}\right)$; $\left.F_{\text {ST95 }}=0.0135\right), S$. spinus (8 loci; 20 individuals; $\left.P S=2.055+0.265 . \ln \left(F_{\mathrm{ST}}\right) ; F_{\mathrm{ST} 95}=0.015\right)$, and $S$. sutor (16 loci; 32 individuals; $\left.P S=1.991+0.232 . \ln \left(F_{\mathrm{ST}}\right) ; F_{\mathrm{ST} 95}=0.011\right)$. Dotted line indicates $95 \%$ significance threshold $\left(F_{\text {ST95). }}\right.$. The relatively low $F_{\text {ST }}$ values observed at this threshold show that fine-scale population structure can be detected using this set of markers 


\section{Molecular Biology Reports}

Supplementary information to:

Characterization of genome wide microsatellite markers for rabbitfishes, an important resource for artisanal fisheries in the Indo-Pacific

Ilkser Erdem Kiper, Paulette Bloomer, Philippe Borsa, Thierry Bernard Hoareau

Correspondence: Molecular Ecology and Evolution Programme, Department of Genetics, University of Pretoria, Pretoria 0002, South Africa

thoareau@gmail.com

Online Resources 1-10 here appended 


\section{Online Resource 1}

List of rabbitfish, Siganus spp. specimens sub-sampled for genetics, with sampling details. MNHN: Muséum national d'histoire naturelle, Paris.

\begin{tabular}{|c|c|c|c|c|}
\hline Species & Specimen no. & Sampling date & Sampling locality & Collector \\
\hline \multicolumn{5}{|c|}{ S. argenteus } \\
\hline & IFA0001 & 11 Dec. 2013 & Mangily, Ifaty, Madagascar & S. Abeare \\
\hline & S006 & 04 Feb. 2005 & Nouméa fish market, New Caledonia & A. Collet \\
\hline \multicolumn{5}{|c|}{ S. canaliculatus } \\
\hline & ScanJurong02 & 21 Nov. 2006 & Jurong fish market, Singapore (from off Phuket, Thailand) & P. Borsa \\
\hline & ScanJurong03 & 21 Nov. 2006 & Jurong fish market, Singapore (from off Phuket, Thailand) & P. Borsa \\
\hline \multicolumn{5}{|c|}{ 舟 } \\
\hline & $\mathrm{T}-392$ & 30 Apr. 2005 & SE side, Conception Is., Seychelles & G. Gouws \\
\hline & S002 & 04 Feb. 2005 & Nouméa fish market, New Caledonia & A. Collet \\
\hline & (MNHN 2007-0006) & & & \\
\hline \multicolumn{5}{|c|}{ S. doliatus } \\
\hline & S003 & 04 Feb. 2005 & Nouméa fish market, New Caledonia & A. Collet \\
\hline & (MNHN 2007-0007) & & & \\
\hline & S007 & 04 Feb. 2005 & Nouméa fish market, New Caledonia & A. Collet \\
\hline & (MNHN 2007-0008) & & & \\
\hline \multicolumn{5}{|c|}{ S. fuscescens } \\
\hline & Sfus04 & June 2006 & Marau, Solomon Islands, & E. Tardy \\
\hline & Sfus05 & June 2006 & Marau, Solomon Islands, & E. Tardy \\
\hline \multicolumn{5}{|c|}{ S. laqueus } \\
\hline & T-66 & 16 Apr. 2005 & Victoria market, Seychelles & G. Gouws \\
\hline & RB09-241 & 01 Dec. 2009 & Mangrove channel, Nampula, Mozambique & G. Gouws \\
\hline & KEN0012 & 14 Mar. 2014 & Msambweni, Kenya & N. Wambiji \\
\hline & KEN0013 & 14 Mar. 2014 & Msambweni, Kenya & N. Wambiji \\
\hline \multicolumn{5}{|c|}{ S. luridus } \\
\hline & KEN0002 & 01 Apr. 2014 & Kilifi, Kenya & N. Wambiji \\
\hline & KEN0003 & 01 Apr. 2014 & Kilifi, Kenya & N. Wambiji \\
\hline & KEN0010 & 13 Mar. 2014 & Msambweni, Kenya & N. Wambiji \\
\hline & KEN0011 & 13 Mar. 2014 & Msambweni, Kenya & N. Wambiji \\
\hline & KEN0018 & 11 Feb. 2013 & Mombasa, Kenya & N. Wambiji \\
\hline & KEN0019 & 11 Feb. 2013 & Mombasa, Kenya & N. Wambiji \\
\hline & KEN0022 & 17 Jan. 2014 & Malindi, Kenya & N. Wambiji \\
\hline & KEN0023 & 17 Jan. 2014 & Malindi, Kenya & N. Wambiji \\
\hline & Slur01 & 2002 & Lattaqieh, Syria & M. Hassan \\
\hline & Slur02 & 2002 & Lattaqieh, Syria & M. Hassan \\
\hline & Slur03 & 2002 & Lattaqieh, Syria & M. Hassan \\
\hline & Slur04 & 2002 & Lattaqieh, Syria & M. Hassan \\
\hline & Slur05 & 2002 & Lattaqieh, Syria & M. Hassan \\
\hline & Slur06 & 2002 & Lattaqieh, Syria & M. Hassan \\
\hline & Slur07 & 2002 & Lattaqieh, Syria & M. Hassan \\
\hline & $\mathrm{Ss} 01$ & - & La Réunion & E. Teissier \\
\hline & $\mathrm{Ss} 02$ & - & La Réunion & E. Teissier \\
\hline \multicolumn{5}{|c|}{ S.puellus } \\
\hline & S004 & 04 Feb. 2005 & Nouméa fish market, New Caledonia & A. Collet \\
\hline \multicolumn{5}{|c|}{ S. punctatus } \\
\hline & S001 & 04 Feb. 2005 & Nouméa fish market, New Caledonia & A. Collet \\
\hline & (MNHN 2007-0010) & & & \\
\hline \multicolumn{5}{|c|}{ S. rivulatus } \\
\hline & Sriv01 & 2002 & Lattaqieh, Syria & M. Hassan \\
\hline & Sriv02 & 2002 & Lattaqieh, Syria & M. Hassan \\
\hline & Sriv03 & 2002 & Lattaqieh, Syria & M. Hassan \\
\hline & Sriv04 & 2002 & Lattaqieh, Syria & M. Hassan \\
\hline & Sriv05 & 2002 & Lattaqieh, Syria & M. Hassan \\
\hline & Sriv06 & 2002 & Lattaqieh, Syria & M. Hassan \\
\hline & Sriv07 & 2002 & Lattaqieh, Syria & M. Hassan \\
\hline \multicolumn{5}{|l|}{ S. spinus } \\
\hline & JNC 1555 & 28 June 2005 & Récif Goéland, New Caledonia & G. Mou-Tham \\
\hline & JNC 1556 & 28 June 2005 & Récif Goéland, New Caledonia & G. Mou-Tham \\
\hline & Sspi01 & 28 June 2005 & Récif Goéland, New Caledonia & G. Mou-Tham \\
\hline & Sspi02 & 13 June 2006 & Ngela, Solomon Is. & E. Tardy \\
\hline & Sspi03 & 19 June 2006 & Ngela, Solomon Is. & E. Tardy \\
\hline & Sspi04 & 27 Aug. 2006 & Manus I., Papua New Guinea & P. Boblin \\
\hline & Sspi05 & 27 Aug. 2006 & Manus I., Papua New Guinea & P. Boblin \\
\hline & Sspi06 & 27 Aug. 2006 & Manus I., Papua New Guinea & P. Boblin \\
\hline & Sspi07 & 27 Aug. 2006 & Manus I., Papua New Guinea & P. Boblin \\
\hline & Sspi08 & 27 Aug. 2006 & Manus I., Papua New Guinea & P. Boblin \\
\hline & Sspi10 & 27 Aug. 2006 & Manus I., Papua New Guinea & P. Boblin \\
\hline & Sspi11 & 27 Aug. 2006 & Manus I., Papua New Guinea & P. Boblin \\
\hline
\end{tabular}




\begin{tabular}{|c|c|c|c|c|}
\hline & Sspi12 & 27 Aug. 2006 & Manus I., Papua New Guinea & P. Boblin \\
\hline & Sspi13 & 27 Aug. 2006 & Manus I., Papua New Guinea & P. Boblin \\
\hline & Sspi14 & 21 Feb. 2007 & Bali barat, Indonesia & F. Giancarlo \\
\hline & Sspi34-12 & 27 Mar. 2006 & Opunohu Bay, Moorea & D. Lecchini \\
\hline & Sspi34-2 1 & 27 Mar. 2006 & Opunohu Bay, Moorea & D. Lecchini \\
\hline & Sspi34-2 2 & 27 Mar. 2006 & Opunohu Bay, Moorea & D. Lecchini \\
\hline & Sspi34-2 3 & 27 Mar. 2006 & Opunohu Bay, Moorea & D. Lecchini \\
\hline \multicolumn{5}{|l|}{ S. sutor } \\
\hline & INS0001 & 31 Mar. 2014 & Inhassoro, Mozambique & A. Brito \\
\hline & INS0002 & 31 Mar. 2014 & Inhassoro, Mozambique & A. Brito \\
\hline & INS0004 & 31 Mar. 2014 & Inhassoro, Mozambique & A. Brito \\
\hline & INS0005 & 31 Mar. 2014 & Inhassoro, Mozambique & A. Brito \\
\hline & INS0006 & 31 Mar. 2014 & Inhassoro, Mozambique & A. Brito \\
\hline & INS0007 & 31 Mar. 2014 & Inhassoro, Mozambique & A. Brito \\
\hline & INS0008 & 31 Mar. 2014 & Inhassoro, Mozambique & A. Brito \\
\hline & INS0009 & 31 Mar. 2014 & Inhassoro, Mozambique & A. Brito \\
\hline & INS0011 & 31 Mar. 2014 & Inhassoro, Mozambique & A. Brito \\
\hline & INS0012 & 31 Mar. 2014 & Inhassoro, Mozambique & A. Brito \\
\hline & INS0013 & 31 Mar. 2014 & Inhassoro, Mozambique & A. Brito \\
\hline & INS0014 & 31 Mar. 2014 & Inhassoro, Mozambique & A. Brito \\
\hline & INS0015 & 31 Mar. 2014 & Inhassoro, Mozambique & A. Brito \\
\hline & INS0018 & 31 Mar. 2014 & Inhassoro, Mozambique & A. Brito \\
\hline & INS0019 & 31 Mar. 2014 & Inhassoro, Mozambique & A. Brito \\
\hline & INS0020 & 31 Mar. 2014 & Inhassoro, Mozambique & A. Brito \\
\hline & INS0022 & 31 Mar. 2014 & Inhassoro, Mozambique & A. Brito \\
\hline & INS0023 & 31 Mar. 2014 & Inhassoro, Mozambique & A. Brito \\
\hline & INS0024 & 31 Mar. 2014 & Inhassoro, Mozambique & A. Brito \\
\hline & INS0025 & 31 Mar. 2014 & Inhassoro, Mozambique & A. Brito \\
\hline & INS0026 & 31 Mar. 2014 & Inhassoro, Mozambique & A. Brito \\
\hline & INS0027 & 31 Mar. 2014 & Inhassoro, Mozambique & A. Brito \\
\hline & INS0028 & 31 Mar. 2014 & Inhassoro, Mozambique & A. Brito \\
\hline & INS0029 & 31 Mar. 2014 & Inhassoro, Mozambique & A. Brito \\
\hline & INS0031 & 31 Mar. 2014 & Inhassoro, Mozambique & A. Brito \\
\hline & INS0032 & 31 Mar. 2014 & Inhassoro, Mozambique & A. Brito \\
\hline & INS0033 & 31 Mar. 2014 & Inhassoro, Mozambique & A. Brito \\
\hline & INS0034 & 31 Mar. 2014 & Inhassoro, Mozambique & A. Brito \\
\hline & INS0035 & 31 Mar. 2014 & Inhassoro, Mozambique & A. Brito \\
\hline & INS0036 & 31 Mar. 2014 & Inhassoro, Mozambique & A. Brito \\
\hline & INS0037 & 31 Mar. 2014 & Inhassoro, Mozambique & A. Brito \\
\hline & INS0038 & 31 Mar. 2014 & Inhassoro, Mozambique & A. Brito \\
\hline & S005 & 04 Feb. 2005 & Nouméa fish market, New Caledonia & A. Collet \\
\hline
\end{tabular}


Online Resource 2

Procedure of selection of the di-, tri- and tetra-nucleotide microsatellite markers from the sequences containing repeats to the design of primers

\begin{tabular}{llll}
\hline Statistic & Length of repeat & & \\
\cline { 2 - 4 } & Di-nucleotide & Tri-nucleotide & Tetra-nucleotide \\
\hline Number of sequences containing repeats & 310 & 61 & 421 \\
$\begin{array}{l}\text { Number of sequences with adequate flanking } \\
\text { regions }\end{array}$ & 56 & 21 & 190 \\
$\begin{array}{l}\text { Number of sequences }>\text { 100bp in length with no } \\
\text { duplicates }\end{array}$ & 28 & 12 & 38 \\
Number of sequences with designed primers & 21 & 5 & 33 \\
\hline
\end{tabular}
a Primers were designed using the program PRIMER DESIGNER v4.20 based on the standard criteria (melting temperature, GC content, presence
of dimers, hairpin and false priming, differential stability between the 5' and 3' ends, and presence of adjacent repeats of the same base). 
Online Resource 3

Details of the 17 polymorphic markers genotyped in Siganus sutor, including locus name, fluorescent dye, repeat motif, annealing temperature $\left(\mathrm{T}_{\mathrm{A}}\right)$ and the allele size range in base pairs

\begin{tabular}{|c|c|c|c|c|}
\hline$\overline{\text { Locus }}$ & Dye & Repeat motif & $\mathrm{T}_{\mathbf{A}}\left({ }^{\circ} \mathrm{C}\right)$ & Allele range (bp) \\
\hline ORLA2-91 b, c & NED & $(\mathrm{GT})_{7}$ & 60 & $134-174$ \\
\hline ORLA8-113b, c & PET & $(\mathrm{CA})_{13}$ & 60 & $161-167$ \\
\hline ORLA11-71 a, c & 6-FAM & $(\mathrm{CA})_{8}$ & 60 & $377-387$ \\
\hline ORLA12-160 b, c & PET & $(\mathrm{CA})_{12}(\mathrm{TA})(\mathrm{CA})_{6}$ & 60 & $283-303$ \\
\hline ORL $A 14-42^{\mathrm{b}, \mathrm{c}}$ & PET & $(\mathrm{CA})_{10}$ & 60 & $368-400$ \\
\hline SIG006 a & NED & $(\mathrm{CAAA})_{9}$ & 55 & $215-251$ \\
\hline SIG007a & VIC & $(\mathrm{CAAA})_{5}(\mathrm{CAGA})(\mathrm{CAAA})_{8}$ & 55 & $191-259$ \\
\hline SIG008 a & 6-FAM & $(\text { ATAG })_{4}($ GTAG $)(\text { ATAG })_{11}$ & 55 & $130-186$ \\
\hline SIG009a & PET & $(\mathrm{AGAT})_{18}$ & 55 & $196-352$ \\
\hline$S I G 010^{a}$ & 6-FAM & $\left(\mathrm{AGAT}_{12}\right.$ & 55 & $238-282$ \\
\hline SIG011 b & VIC & $(\mathrm{AGAT})_{16}$ & 55 & $184-268$ \\
\hline SIG013b & 6-FAM & $\left(\mathrm{GTT}^{*} \mathrm{~T}\right)_{11}$ & 57 & $266-282$ \\
\hline SIG014 a & VIC & $\left(\mathrm{GTT}^{\circ} \mathrm{T}\right)_{11}$ & 55 & $333-369$ \\
\hline SIG015b & NED & $\left(\right.$ CTTT $_{11}($ CTCT $)\left(\text { CTTT }_{6}\right)_{6}$ & 55 & $243-299$ \\
\hline SIG017a & PET & $(\mathrm{CAG})_{8}$ & 55 & $102-117$ \\
\hline SIG019b & 6-FAM & $(\mathrm{GTT})_{12}$ & 55 & $187-235$ \\
\hline SIG020 a & NED & $(\mathrm{ACC})_{15}$ & 57 & $115-157$ \\
\hline
\end{tabular}

a Multiplex combination 1

b Multiplex combination 2

c Primer set from Gotoh et al. (2013) 
Online Resource 4

Details of the 59 microsatellite markers designed from the repeat-enriched library obtained for Siganus sutor, including locus name, forward and reverse primer sequences, repeat motif and size of microsatellite amplicon in base pairs

\begin{tabular}{|c|c|c|c|c|}
\hline Locus & Forward primer $5^{\prime}-3^{\prime}$ & Reverse primer $5^{\prime}-3^{\prime}$ & Repeat motif & Amplicon size (bp) \\
\hline SIG001 & GTGGCACGAACAACACATGA & GGGCT'TGGCAAGTCACGAAGTC & $(\mathrm{ATCT})_{10}$ & 231 \\
\hline SIG002a & CTTGGCAAGCAATGGAAGC & AGTGAGTTGCCTGGAAAG & $(\mathrm{ATCT})_{21}$ & 308 \\
\hline SIG003 a & ACATTTAGCGTGGGAGAC & TTCTGCATCAGACTGAAC & $(\mathrm{ATCT})_{12}$ & 153 \\
\hline SIG004a & CCTCCGTGGAAGTCAACAG & AATCATGGCGACTGTTGAGC & $(\mathrm{GT})_{9}$ & 175 \\
\hline SIG005 a & GTCGAAGGTCGTAGTTCTTG & GCATGCCTGTGACTGTCAAC & $(\mathrm{ATCT})^{13}$ & 261 \\
\hline SIG006a, b & АACTGTGTGAGCGATCTG & TCAGTACAGCGTGACATC & $(\mathrm{CAAA})_{9}$ & 237 \\
\hline SIG007a, b & AAACAAACGTCCGGAAAC & GGTCAGTCAGCATCGTAA & $(\mathrm{CAAA})_{5}(\mathrm{CAGA})(\mathrm{CAAA})_{8}$ & 265 \\
\hline SIG008 a, b & TGCTAAATGTCCCTTCAC & TGGATCTGTGCTACCTAC & $(\mathrm{ATAG})_{4}(\mathrm{GTAG})(\mathrm{ATAG})_{11}$ & 160 \\
\hline SIG009a, b & ТССТGСТАСССАСТССТТС & АTTACAGGAAGCGGAAAC & $\left(\mathrm{AGAT}_{18}\right.$ & 243 \\
\hline SIG010 a, b & ATCTGACGGATACGATTC & TCGAGCAGAATGGCACTCAG & $(\text { AGAT })_{12}$ & 269 \\
\hline SIG011 a, b & TTCTCCTAGGCCTGGAGATG & ССТССТСТАATGСАССТАТ & $(\mathrm{AGAT})_{16}$ & 211 \\
\hline SIG012 a & GGCTCGTTGACCTCTCAG & AGAACAAACTCCGGAAAC & $\left(\text { GTTT }^{8}\right)^{8}$ & 293 \\
\hline SIG013a, b & CGGCTCTTTTGTGTCTGT & ACAATGTTGCGCTCACTC & $(\text { GTTT) })_{11}$ & 269 \\
\hline SIG014 a, b & TGGCTGTTCCTTACTGTCT & TATGACGGCCACTAGATG & $\left(\mathrm{GTT}^{\prime \prime T}\right)_{11}$ & 354 \\
\hline SIG015 a, b & GGGGAGAGAAATGATAGC & CCGCATTAGTAATTGGTC & $\left(\right.$ CTTT $_{11}($ CTCT $)\left(\right.$ CTTT $_{6}$ & 279 \\
\hline SIG016 a & GGCTATGCACTGATTCAC & АCАТААТСССАТСАGCAG & $(A G C)_{8}$ & 124 \\
\hline SIG017 a, b & GAGTGGGTGTCCTGAATG & AGCATCAATAGACGTGTG & $(\mathrm{CAG})_{8}$ & 111 \\
\hline SIG018 a & ACTGATGAGCTGGTT'TTC & TGCTGCTGTCAGCAGTTC & $(\mathrm{AGG})_{9}$ & 115 \\
\hline SIG019 a, b & AAGTAGCGCCACCTTCTG & TGACAGCTTGCAGCAGAA & $(\mathrm{GTT})_{12}$ & 198 \\
\hline SIG020 a, b & TCTGAACCATGAGCTTCC & TCGAACGGAGACGCTTCA & $(\mathrm{ACC})_{15}$ & 138 \\
\hline SIG021 & СТTCTCGCCTTCCAGCTCATC & TGTGATGAGTACCTGAGTAA & (CTT'T) $)_{10}$ & 349 \\
\hline SIG022 & GAGGCAGTGACAGCCTGTCT & GTAAGGTGCTGCAGCAGGATG & $\left(\mathrm{CTTT}_{14}\right.$ & 189 \\
\hline SIG023 & ACACAGGACCTGCAAGAGA & TGCGGATAGGCTCCAATGACC & $(\mathrm{ATCT})_{14}$ & 268 \\
\hline SIG024 & ATGAGACCGTACATCTTCATC & TTGTTGGGTTTAGTTCTAGGA & $(\mathrm{GT})_{13}$ & 173 \\
\hline SIG025 & CCAATGCAGCACATTCAGT & GGATGTTGTAGCAGCCTCCA & $(\mathrm{GT})_{11}$ & 130 \\
\hline SIG026 & ТТТССТСТАССАССТСТСАТС & CGAATGACTTCGCTGGAAC & $(\mathrm{ATCT})_{10}$ & 223 \\
\hline SIG027 & TCAGAACCGCCTCTCACTGC & AAGAAGTACGAGTGATAGAG & $(\mathrm{CT})_{9}$ & 163 \\
\hline SIG028 & GGGGGCGCAATAGTAAGATG & TCAGATTGGAGGCCACAATCC & $(\mathrm{ATCT})_{19}$ & 245 \\
\hline SIG029 & TCCTCTGCCATTAGGTTCTG & GGCGTAAACTTACAGTACA & $(\mathrm{GT})_{9}$ & 150 \\
\hline SIG030 & TTATGCCACACTGGAGGTTC & ССTCССTTGATGTGGAGTAG & $(\mathrm{GT})_{11}$ & 160 \\
\hline SIG031 & ССАСАACACACAТАТАСАС & GTGCAGCAGTAAGGTGGTCT & $(\mathrm{ATCT})_{15}$ & 204 \\
\hline SIG032 & F:GAGGGCTTCTCTTACAGTAG & ATGGAGGCGAGAGGCAGAGA & $(\mathrm{ATCT})_{19}$ & 294 \\
\hline SIG033 & CATCAACAGGTTGGCTACAG & GTACCAGCCTGGAAACTAGC & $(\mathrm{GT})_{8}$ & 156 \\
\hline SIG034 & TCCTCATCGCACTCGCCAGA & ACGCAGATCGTGATGAGTC & $(\mathrm{ATCT})_{13}$ & 300 \\
\hline SIG035 & GGCAGTGCTGGTGGATCTAC & ACGCAGAGGAAACACAGAAC & $(\mathrm{GT})_{9}$ & 152 \\
\hline SIG036 & GTGGCCGTTCTTATATTATG & CTAATGAGGTCGAGTCC & $(\mathrm{GT})_{8}$ & 136 \\
\hline SIG037 & CAGCGCTGATGGCACAATCC & СТТСТСТССТТ'ТТT'ТСТТАС & $(\mathrm{GT})_{18}$ & 224 \\
\hline SIG038 & GGATGAAAACATCGGAGTC & GACTGCACAACACAGCTATGG & $(\mathrm{AGAT})_{15}$ & 193 \\
\hline
\end{tabular}




\begin{tabular}{|c|c|c|c|c|}
\hline SIG039 & GTGGGGCCAATATCTGTGGG & AGCCTGGCCAATATCTGAGTG & $(\mathrm{ATCT})_{12}$ & 208 \\
\hline SIG040 & TGACGACTAGGCTAGCAGAG & АСССТСAGGCTCCAATAССТT & $(\mathrm{AAAC})_{13}$ & 194 \\
\hline SIG041 & CTGGATGCACAGGTGTGTA & GGTTCACAGGTGGCTGCTGCTG & $(\mathrm{AAAC})_{13}$ & 236 \\
\hline SIG042 & CTGGGTCGAGTCGCCCCC & TGCTTCTGTCGTTGCATCAG & $(\mathrm{AAAC})_{10}$ & 166 \\
\hline SIG043 & ACCTGCCATCTGTATCATTC & CATGGCGGGAAACGTTCTGAGC & $(\mathrm{AC})_{8}$ & 122 \\
\hline SIG044 & CGTAGCCCGTGGCCGTGTAG & CGTTAGCCCGTCCACGGCGT & $(\mathrm{AC})_{11}$ & 164 \\
\hline SIG045 & AGTGTATGAGGACGAGCGG & TGTTGTCTCACTTTACAACAACAC & $(\mathrm{AAAC})_{9}$ & 236 \\
\hline SIG046 & TCAACAACTGGAATCAACAAACTG & CTGATCTCCGTGCTCCACC & $(\mathrm{AAAC})_{13}$ & 248 \\
\hline SIG047 & AGAAACAAACGTCCGGAAAC & CСTGAGTAATCATCTCCGGC & $(\mathrm{AAAC})_{8}$ & 311 \\
\hline SIG048 & TGACTCATGCACAAGTACATCC & TTTGTGGTAATATACAGGGCGG & $(\mathrm{AAAC})_{13}$ & 187 \\
\hline SIG049 & АСАСАСТССССТАТТССТGС & TAACGTCTGGGACGAGAGC & $(\mathrm{AGAT})_{17}$ & 197 \\
\hline SIG050 & TCACGCTCAGCAAGTAACC & ACTGGTGAGACTATTCTTGGC & $(\mathrm{AAAC})_{10}$ & 176 \\
\hline SIG051 & ACTGTTGCCATAGTGAAGTGC & AGCGCACTGTGTCCATTAG & $(\mathrm{AC})_{8}$ & 161 \\
\hline SIG052 & АCATTTATGTCTTAGCAACGGGG & ACAAAGTGGAGGCGAACTG & $(\mathrm{AC})_{11}$ & 181 \\
\hline SIG053 & TCCCCACAGTGTTTCCACC & ACAGCTTTTGGCCCTTCAG & $(\mathrm{AC})_{10}$ & 232 \\
\hline SIG054 & АСАСТСТСАСАCAGACCTGC & ACGGCGAGCCTACTTACTTC & $(\mathrm{AC})_{20}$ & 221 \\
\hline SIG055 & GCCGGTCTGGTAGTCAAAAC & ATTAGTGTTGGACAAATGCCCC & $(\mathrm{AC})_{9}$ & 159 \\
\hline SIG056 & CTCTTACGTGCATACACAGTTG & AAAGTATGGCCCGGCAGATG & $(\mathrm{AC})_{10}$ & 151 \\
\hline SIG057 & GGGATGAAGTGGTAGAAGAAGC & ATGATGTCCACGGAGAGCC & $(\mathrm{AC})_{13}$ & 155 \\
\hline SIG058 & CCAACCTGCACGCTCTATC & GATCGCGGTCAAAGGTCAAC & $(\mathrm{AC}) 12$ & 152 \\
\hline SIG059 & CGTACTGATCACCGATGGC & ACCTTTTGTACAGCGACCTTG & $(\mathrm{AC})_{12}$ & 162 \\
\hline
\end{tabular}

${ }^{a}$ Primer pair tested for PCR-amplification in other Siganus spp.

b Primer pair used for genotyping in S. luridus, S. rivulatus, S. spinus, and S. sutor 


\section{Online Resource 5}

GenBank accession numbers for cytochrome $b$-gene sequences of Siganus spp.

\begin{tabular}{ll}
\hline Species & GenBank accession no. \\
\hline $\begin{array}{l}\text { S. argenteus } \\
\text { S. canaliculatus }\end{array}$ & AB276798-AB276814; AY190542; DQ898028-DQ898036; EF210174 \\
S. corallinus & EF210176; GU929677 \\
S. doliatus & AB276925, AB276926, AB276928, AB276930, AB276931 \\
S. fuscescens & AB276951-AB276957, AB276960; DQ898038 \\
& AB276822-AB276825, AB276830; GU929680-GU929684; HQ843182-HQ843185, HQ843187- \\
S. luridus & HQ843191, HQ843196, HQ843197, HQ843200, HQ843201, HQ843209-HQ843217, HQ843227, \\
S. punctatus & DQ898056-DQ898058; EF210185, EF210186 \\
S. puellus & AB276873-AB276880; DQ898068-DQ898074, DQ898092; EF210187 \\
S. rivulatus & AB276855-AB276867; DQ898063-DQ898067 \\
S. spinus & DQ898075-DQ898078 \\
S. sutor & AB276815-AB276821; AY190545, AY190554; DQ898079-DQ898082; EF210189-EF210192 \\
S. vulpinus & EF210193, EF210194 \\
\hline
\end{tabular}

Some of the sequences available from GenBank were dismissed because of suspected misidentification, $\mathrm{mtDNA}$ introgression or cryptic species. These included AB276924-AB276931 labelled S. corallinus and AB276834-AB276850, DQ274055, EF210175, GU929678, GU929679 labelled S. canaliculatus 
Online Resource 6

Cytochrome b-gene sequences of Siganus spp. that were newly generated, including species name, specimen identification number (ID), sampling location and GenBank number

\begin{tabular}{llll}
\hline Species & Specimen ID & Sampling location & GenBank no. \\
\hline S. laqueus & & MF326182 \\
RB09-241 & Mozambique & MF326187 \\
T-66 & Seychelles & MF326163 \\
KEN0001 & Kenya & MF326164 \\
KEN0012 & Kenya & MF326165 \\
KEN0013 & Kenya & MF326166 \\
KEN0030 & Kenya & MF326188 \\
TZW067 & Tanzania & \\
& & MF326167 \\
R0301-211 & La Réunion & MF326168 \\
R0301-212 & La Réunion & MF326169 \\
R0301-213 & La Réunion & MF326170 \\
R0301-214 & La Réunion & MF326171 \\
R0301-215 & La Réunion & MF326173 \\
R0301-216 & La Réunion & MF326174 \\
R0301-217 & La Réunion & MF326175 \\
R0301-218 & La Réunion & MF326176 \\
R0301-219 & La Réunion & MF326177 \\
R0301-220 & La Réunion & MF326178 \\
R0301-221 & La Réunion & MF326179 \\
R0301-222 & La Réunion & MF326180 \\
R0301-223 & La Réunion & MF326181 \\
R0301-224 & La Réunion & MF326183 \\
R0301-225 & La Réunion & MF326184 \\
Ssut10 & Rodrigues & MF326185 \\
Ssut14 & Rodrigues & MF326186 \\
Ssut17 & Rodrigues & Rodrigues & \\
Ssut21 & & \\
& & &
\end{tabular}




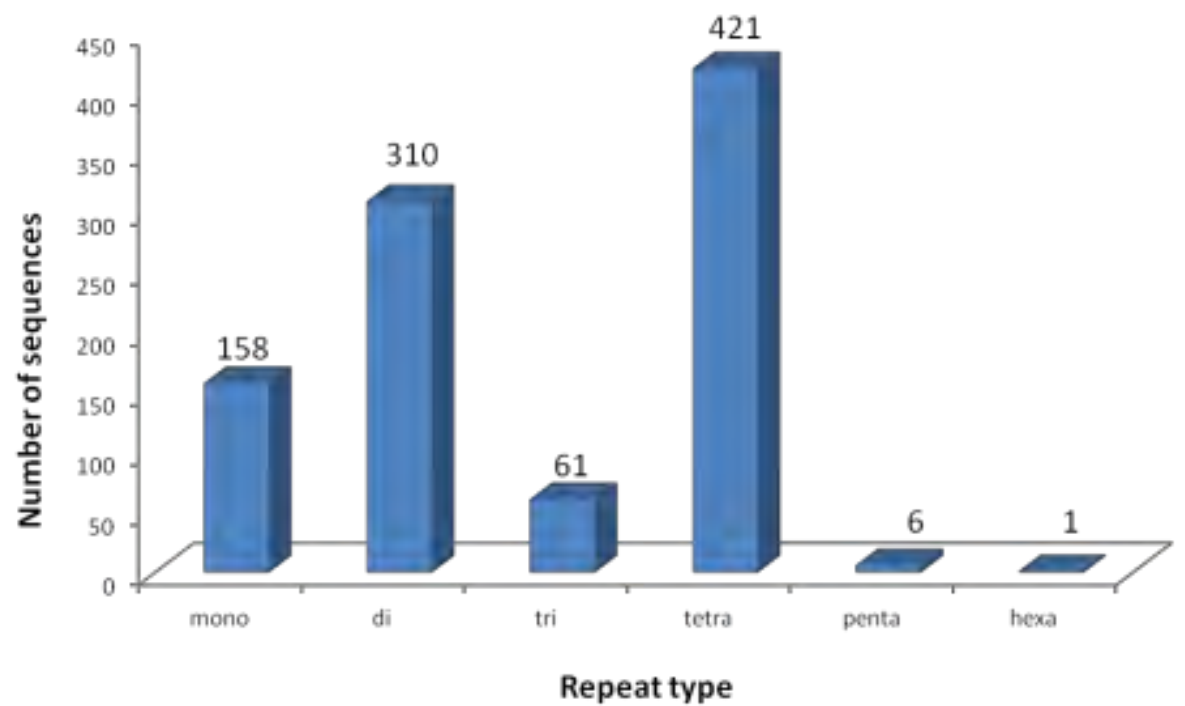

Online Resource 7

Repeat-containing library information for Siganus sutor. Frequency of repeat types in the library (6112 sequences obtained by 454 pyrosequencing). The search criteria for the different repeat types were: $\geq 10$ repeat motifs for mono-nucleotide; $\geq 8$ for di-, tri- and tetra-nucleotide; $\geq 4$ for penta- and hexa-nucleotide. 
Online Resource 8

Siganus spp. Species-pairwise Kimura-2-Parameter net mean genetic distance among species, based on cytochrome $b$-gene nucleotide sequences

\begin{tabular}{|c|c|c|c|c|c|c|c|c|c|c|c|c|c|}
\hline \multirow[t]{2}{*}{ Species } & \multicolumn{13}{|c|}{ Species } \\
\hline & 1 & 2 & 3 & 4 & 5 & 6 & 7 & 8 & 9 & 10 & 11 & 12 & 13 \\
\hline 1. S. argenteus & - & & & & & & & & & & & & \\
\hline 2. S. canaliculatus & 0.164 & - & & & & & & & & & & & \\
\hline 3. S. corallinus & 0.140 & 0.129 & - & & & & & & & & & & \\
\hline 4. S. doliatus & 0.157 & 0.140 & 0.011 & - & & & & & & & & & \\
\hline 5. S. fuscescens & 0.130 & 0.057 & 0.144 & 0.149 & - & & & & & & & & \\
\hline 6. S. laqueus & 0.150 & 0.100 & 0.092 & 0.111 & 0.130 & - & & & & & & & \\
\hline 7. S. luridus & 0.147 & 0.119 & 0.178 & 0.204 & 0.131 & 0.156 & - & & & & & & \\
\hline 8. S. puellus & 1.370 & 0.105 & 0.096 & 0.116 & 0.136 & 0.061 & 0.145 & - & & & & & \\
\hline 9. S. punctatus & 1.590 & 0.110 & 0.090 & 0.103 & 0.134 & 0.014 & 0.166 & 0.064 & - & & & & \\
\hline 10. S. rivulatus & 0.166 & 0.059 & 0.176 & 0.118 & 0.064 & 0.127 & 0.134 & 0.115 & 0.131 & - & & & \\
\hline 11. S. spinus & 0.202 & 0.120 & 0.184 & 0.178 & 0.088 & 0.161 & 0.146 & 0.177 & 0.165 & 0.119 & - & & \\
\hline 12. S. sutor & 0.165 & 0.036 & 0.161 & 0.073 & 0.051 & 0.111 & 0.126 & 0.129 & 0.128 & 0.035 & 0.125 & - & \\
\hline 13. S. vulpinus & 1.132 & 0.121 & 0.103 & 0.116 & 0.130 & 0.061 & 0.141 & 0.062 & 0.059 & 0.128 & 0.162 & 0.134 & - \\
\hline
\end{tabular}


Online Resource 9

Pairwise linkage disequilibrium estimates in S. spinus

\begin{tabular}{|c|c|c|c|c|c|c|c|c|}
\hline \multirow[t]{2}{*}{ Locus } & \multicolumn{8}{|l|}{ Locus } \\
\hline & ORLA2-91 & $\begin{array}{l}\text { ORLA11- } \\
71\end{array}$ & $\begin{array}{l}\text { ORLA14- } \\
42\end{array}$ & $\begin{array}{l}\text { ORLA8- } \\
113\end{array}$ & $\begin{array}{l}\text { ORLA12- } \\
160\end{array}$ & SIG006 & SIG011 & SIG017 \\
\hline ORLA2-91 & - & & & & & & & \\
\hline ORLA11-71 & 0.753 & - & & & & & & \\
\hline ORLA14-42 & 0.959 & 0.792 & - & & & & & \\
\hline ORL $A 8-113$ & 0.998 & 0.560 & 0.902 & - & & & & \\
\hline $\begin{array}{l}\text { ORL A12- } \\
160\end{array}$ & 0.998 & 0.346 & 0.992 & 0.998 & - & & & \\
\hline SIG006 & 0.216 & 0.691 & 0.925 & 0.205 & 0.186 & - & & \\
\hline SIG011 & 0.620 & 0.532 & 0.915 & $0.107^{*}$ & $0.262^{*}$ & 0.170 & - & \\
\hline SIG017 & 0.661 & 0.171 & 0.923 & 0.487 & 0.499 & 0.455 & 0.640 & - \\
\hline
\end{tabular}

$* P<0.05$ (1000 permutations) 
Online Resource 10

Pairwise linkage disequilibrium estimates in Siganus sutor

\begin{tabular}{|c|c|c|c|c|c|c|c|c|c|c|c|c|c|c|c|c|}
\hline \multirow[t]{2}{*}{ Locus } & \multicolumn{16}{|l|}{ Locus } \\
\hline & $\begin{array}{l}\text { ORLA } \\
\text { 2-91 }\end{array}$ & $\begin{array}{l}\text { ORLA } \\
11-71\end{array}$ & $\begin{array}{l}\text { ORLA } A \\
14-42\end{array}$ & $\begin{array}{l}\text { ORLA } \\
8-113\end{array}$ & $\begin{array}{l}\text { ORLA } \\
12-160\end{array}$ & SIG006 & SIG007 & SIG008 & SIG009 & SIG010 & SIG011 & SIG013 & SIG015 & SIG017 & SIG019 & SIG020 \\
\hline ORLA2-91 & - & & & & & & & & & & & & & & & \\
\hline ORLA11-71 & 0.822 & & & & & & & & & & & & & & & \\
\hline ORLA14-42 & 1 & 0.886 & - & & & & & & & & & & & & & \\
\hline ORLA8-113 & 0.287 & 0.620 & 0.097 & - & & & & & & & & & & & & \\
\hline ORL A12-160 & 0.997 & 0.745 & 0.994 & 0.207 & - & & & & & & & & & & & \\
\hline SIG006 & 1 & 0.514 & 1 & 0.199 & 0.929 & - & & & & & & & & & & \\
\hline SIG007 & 1 & 0.998 & 1 & 0.231 & 0.989 & 1 & & & & & & & & & & \\
\hline SIG008 & 1 & 0.736 & 1 & 0.192 & 0.949 & 0.896 & 0.998 & - & & & & & & & & \\
\hline SIG009 & 1 & 0.990 & 1 & 0.941 & 1 & $1 *$ & 1 & 1 & - & & & & & & & \\
\hline SIG010 & 1 & 0.997 & 1 & 0.524 & 1 & 1 & 1 & 1 & $1 *$ & - & & & & & & \\
\hline SIG011 & 1 & 0.979 & 1 & 0.353 & 0.999 & 1 & 1 & 0.785 & $1 *$ & $1 *$ & - & & & & & \\
\hline SIG013 & 0.986 & 0.343 & 0.859 & 0.770 & 0.555 & 0.260 & 0.537 & 0.091 & 1 & 0.995 & 0.511 & - & & & & \\
\hline SIG015 & 1 & 0.769 & 1 & 0.230 & 0.991 & 1 & 1 & 1 & 1 & 1 & 1 & 0.900 & - & & & \\
\hline SIG017 & 0.915 & 0.271 & 0.734 & 0.452 & 0.634 & 1 & 0.970 & 0.990 & 1 & 0.953 & 0.776 & 0.921 & 0.933 & - & & \\
\hline SIG019 & 1 & 0.831 & 1 & 0.604 & 0.998 & 1 & 1 & 0.999 & 1 & 1 & 1 & 0.904 & 1 & 0.954 & - & \\
\hline SIG020 & 1 & 0.437 & 1 & 0.425 & 0.999 & 0.889 & 1 & 0.615 & $1 *$ & 1 & 0.977 & 0.972 & 1 & 0.502 & 0.954 & - \\
\hline
\end{tabular}

$* P<0.05$ (1000 permutations) 